\title{
Entrevista com Frei Alamiro
}

José Alamiro Andrade Silva (27/05/1940) nasceu em Três Pontas e em sua caminhada passou por momentos fortes da vida do povo pobre de nosso país. Esteve na luta em defesa dos direitos humanos e da luta pela anistia, ao lado do prêmio Nobel da Paz Adolfo Pérez Esquivel. Solidário como os mais fracos, nos dramáticos enfrentamentos com a repressão ao movimento dos trabalhadores em São Bernardo, continua um militante da "firmeza permanente", como ele prefere chamar esse modo de construir um mundo novo, sem injustiças e exploração.

A entrevista recupera momentos da história recente de nosso povo e valoriza a persistência em ideais de mudança e luta pela paz e pela justiça, como as greves de São Bernardo e ações para salvar vidas da repressão no Brasil e na América Latina.

C \& LC - Comecemos sobre a origem do convento Santo Antônio do Largo da Carioca, Rio de Janeiro. Frei Vicente de Salvador, fundador deste convento, é o autor da primeira história do Brasil. Isso confirma a importância dos religiosos na formação cultural brasileira?

Considerando a formação cultural brasileira a partir da chegada dos europeus, quando Pedro Álvares Cabral chega ao Brasil, junto dele vieram 12 franciscanos, entre eles Frei Henrique de Coimbra, que presidia o grupo.

Não se pode negar que eles vieram entusiasmados para pregar o Evangelho por toda a parte, mas os primeiros franciscanos não vieram apenas com intenções religiosas. Naquela época, a Igreja, através das suas Congregações, era detentora do saber, inclusive do saber científico. Muitos deles vieram porque conheciam as rotas através das estrelas, vieram como assessores científicos para que Pedro Álvares Cabral chegasse aonde ele tinha que chegar.

Os franciscanos e as outras ordens religiosas participaram decisivamente desta formação, por exemplo, o primeiro nome do país era Terra de Santa Cruz, depois é que prevaleceu o nome comercial de Pau-Brasil.

Entre os franciscanos, jesuítas e carmelitas, que também estavam muito presentes naquela época, segundo o historiador uruguaio Mario Cayota os que tinham a melhor acolhida popular em toda a América Latina, principalmente da parte dos índios, eram os seguidores de Francisco. Os índios diziam: "Eles são iguais a nós, andam descalços e estão próximos”. Você pode ver que na América as igrejas franciscanas têm um influxo popular muito grande. Uma série de fatores que levaram - os Capuchinhos ainda mais do que nós - a uma proximidade, uma integração com o povo.

Estiveram muito presentes, logo no começo, deste convento e o de Olinda. Mas presentes sempre dentro daquele contexto de padroado, no qual quem nomeava o 


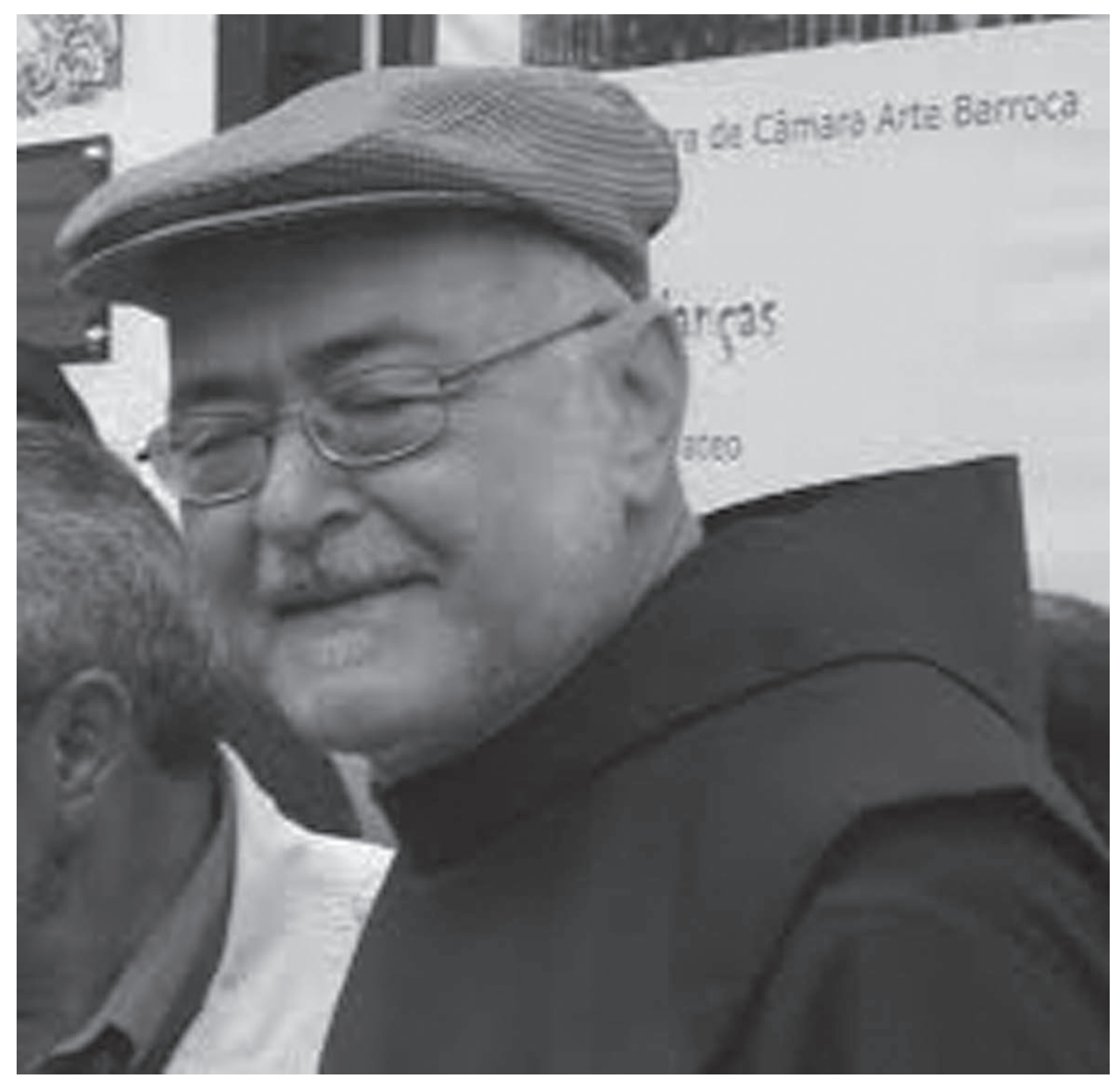

superior da casa era o governo. Quem nomeou frei Salvador - guardião deste convento - foi sua Majestade. Na cidadezinha onde nasci - Três Pontas, em Minas Gerais -, o pároco local - padre Victor, em 1850 - foi nomeado por Dom Pedro II, naquele regime de casamento espúrio entre a Igreja e o Estado.

A avaliação de quais foram as contribuições positivas e negativas é outra discussão, mas, que estavam presentes, como ainda estão até hoje. Ontem um colega, durante um café me disse: "você que estava mais envolvido com a questão política..." e eu respondi que todos estamos envolvidos. Talvez ele até mais do que eu, mas com posições diferentes. Eu disse que, talvez, ele estivesse muito envolvido em manter tudo o que está aí, lendo o Globo todo o dia. Não dá para não se ter uma posição política, até quem diz não se envolver, isso já é uma posição política.

\section{C \& LC - Depois de ter falado da relação dos franciscanos com a história do} Brasil, fale da sua história pessoal, como foi a sua ligação com os franciscanos?

Eu sou do sul de Minas Gerais, da cidade de Três Pontas, mesma cidade que o Milton Nascimento assume a cidadania, ele nasceu no Rio, mas foi para lá, porque os pais de criação dele eram de lá. A região é conhecida pela monocultura do café, a casa onde eu nasci, que era uma fazenda do tempo da escravidão, tinha a senzala. Meu pai era retireiro [trabalhador de uma fazenda], cuidava do gado e do entorno da fazenda. Mais tarde o meu primo Luís Fernando estava em um seminário em 
Guaratinguetá, como éramos muito amigos, eu quis ir para lá também, mas nem sabia o que era, tinha 11 anos. Eu fui para Guaratinguetá estudar, mais tarde fui descobrir que aquilo era um seminário franciscano.

Estudei em Agudos, perto de Bauru, o noviciado fiz em Rodeio, Santa Catarina, estudei filosofia em Curitiba, teologia em Petrópolis e, foi na caminhada, como diz o Vandré, que as visões vão se clareando, você vai descobrindo e vai percebendo as razões porque sim e porque não. E entre nós a qualquer momento você pode sair, não é só porque entrou. Eu entrei em etapas, tinha 21 anos quando fiz o noviciado, peguei o hábito franciscano que é um passo mais decisivo porque você estuda filosofia, teologia, se aprofundando no que é o franciscanismo e pensando se é isso que você quer.

Quando eu terminei meu curso de Teologia, aqui em Petrópolis, e fui transferido para São Paulo, fui morar na Vila Guilherme, naquele tempo era um lixão, os piscinões que existiam na beirada do Rio Tietê foram todos aterrados com lixo da cidade. Isso de 1968 em diante, e quando vinha a chuva, vinha a enchente. A água não tinha para onde ir, já que tinham tampado os piscinões naturais. Uma das causas para as enchentes em São Paulo. Depois tiveram que construir os piscinões, por que não deixaram os naturais? Isso porque o ser humano é inteligente, imagina se não fosse.

Eu fui trabalhar com o Frei Luís Maria Sartori, que dirigia uma Pastoral Operária. Ele era um grande batalhador, todo mundo tirava o chapéu diante dele, mas a postura dele era muito de conciliação de classes. Ele tinha posição no conflito, mas ele achava que tinha que propor a conciliação de classes.

Mais tarde, em 1972, conheci a Frente Nacional do Trabalho, liderada por Mario Carvalho de Jesus, Salvador Pires, João Breno, Santo Dias e Waldemar Rossi. Entrando neste meio, percebi melhor que eu não tinha essa formação econômica e política, a gente não tem, mas com este contato fui percebendo que há uma divisão de classe na empresa de trabalho, que provoca uma relação esquizofrênica. Então, você propor conciliação de classes é querer queimar uma etapa, pode ser até uma meta de chegada, mas no momento você tem luta de classes, não tem conciliação.

Daí com o pessoal da Frente Nacional, que eram advogados que só admitiam causas trabalhistas, assessoravam os sindicatos, fui entrando neste meio e percebi que apesar de todo o valor, de toda a contribuição do colega, esse caminho começou a não me satisfazer mais, tinha que buscar outros caminhos.

Então, o pessoal da Frente Nacional, trocou o nome, que é tremendamente infeliz, "não violência", do Mahatma Gandhi, do Luther King, e de outros exemplos daqui do Brasil mesmo, para o que usávamos, "firmeza permanente". Nossa metodologia, nossa mística, é a da firmeza permanente, porque se formos partidários da justiça, então basta ficarmos firmes, que mais cedo ou mais tarde venceremos.

E, aí, entra toda uma dinâmica de luta, de trabalho, de posicionamento. Mahatma Gandhi, Luther King, e para mim como religioso foi interessante, pois à medida que os fui descobrindo, comecei a reler a Bíblia com outro enfoque. Comecei a reler a vida de São Francisco, também com outro enfoque. E lá você encontra esses ensinamentos. Cristo era tremendamente não violento. São Francisco era não violento. Só que o sistema tentou cortar os dentes dele, transformá-lo em um cachorro que não morde. Mas, na realidade, se formos ver a vida deles: o Cristo, por que foi morto? Porque ele fazia milagres, curava doentes? Não, foi morto porque na hora em que ele ensinou o povo a rezar, sem passar pelo templo, onde estava o banco central do 
estado israelita, ele esvaziou a contribuição paga no templo, mexeu com a economia. Entrou em choque e lhe sobrou a morte.

E o trabalho que a gente fazia era no sentido de ter claro isso, e também treinar a luta da firmeza permanente, não violenta. Isso não é improvisado, e também não é um trabalho individual. Você tem que ter o apoio da massa toda, embora não possa contar com ela em todos os graus de intensidade, mas de alguma forma tem que ter o apoio da massa. A gente viu isto bem claro no $1^{\circ}$ de Maio de 1979 , que participamos em São Bernardo, em que cinco mil trabalhadores se reuniram na Catedral e foram cercados pelo Exército.

Ficamos espremidos, mas, em compensação, o trabalho foi tão bem feito que havia nas ruas 300 mil pessoas cercando o Exército. Eles ficaram espremidos como um sanduíche, entre nós e aqueles 300 mil. E as pessoas colocavam flores no fuzil dos soldados e gritavam "você soldado, também é explorado", e às vezes ele era parente de outro que estava em greve. Criamos um fato que para mim foi a experiência mais volumosa de não violência que eu vivi.

Lembro que o Teotônio Vilela, que estava todos os dias lá, firme, quando viu aquilo, falou para o Comandante do Exército: "O senhor esteja certo que vai ficar sozinho. O senhor vai ligar para o Governador, ele não vai estar em casa, você vai ter que tomar a decisão sozinho. E se você não liberar isso aqui, veja em volta, vai ser um banho de sangue aqui em São Bernardo, e o culpado será o senhor”. Ele acabou liberando. Recolheram o armamento nos caminhões e foram embora, a turma tomou conta da rua. E, de fato, foi assim, ficamos sabendo que ele saiu dali e foi ligar para o Governador, o Paulo Maluf, que não estava em casa. Telefonou para o Segundo Exército, ninguém atendeu.

Você precisa treinar estes 300 mil, não pode improvisar. Eu fui aprendendo isso e tentando ver isso na religião, no Evangelho, na Bíblia, mas, sobretudo, no Novo Testamento, pois no Antigo tem cabeça rolando para tudo quanto é lado, guerras, era um deus guerreiro. Então eu entrei nessa luta, só que com um enfoque franciscano, nunca abandonei, porque senão a gente se enfraquece. Por exemplo, de partido político eu nunca participei. Algum padre que queira entrar em um partido político, ser candidato, vai depender muito da situação. Vi uma cidadezinha do sul de Minas, aonde o padre era a pessoa melhor indicada para ser o prefeito. Ele tinha que viajar para Belo Horizonte, conversar com autoridades, e ele era a pessoa mais preparada. Mas para mim, em princípio, se eu entrar em um partido político, ou em um cargo político, eu me enfraqueço. Como frade comprometido com tudo isso, em uma linha dessas, tenho muito mais força de atuação do que como político. Se tenho o mais, por que querer o menos? Embora a gente tenha que contar também com o político.

\footnotetext{
C \& LC - A relação da política com a religião está muito presente em nossa história. Qual a participação de frei Sampaio na emancipação política?

O nome dele era Francisco Teodoro Sampaio, estamos neste momento da entrevista no espaço que era a cela, o quarto onde ele morava. Ele nasceu no Rio de Janeiro, de uma família abastada. Ele era muito inteligente e contava com o apoio do superior dele, que era chamado de guardião da casa e o provincial que era uma instância superior, todos com lucidez, então ele contava com essa retaguarda interna. Os franciscanos daquela época eram, na sua maioria, favoráveis à independência, devia ter alguns que
} 


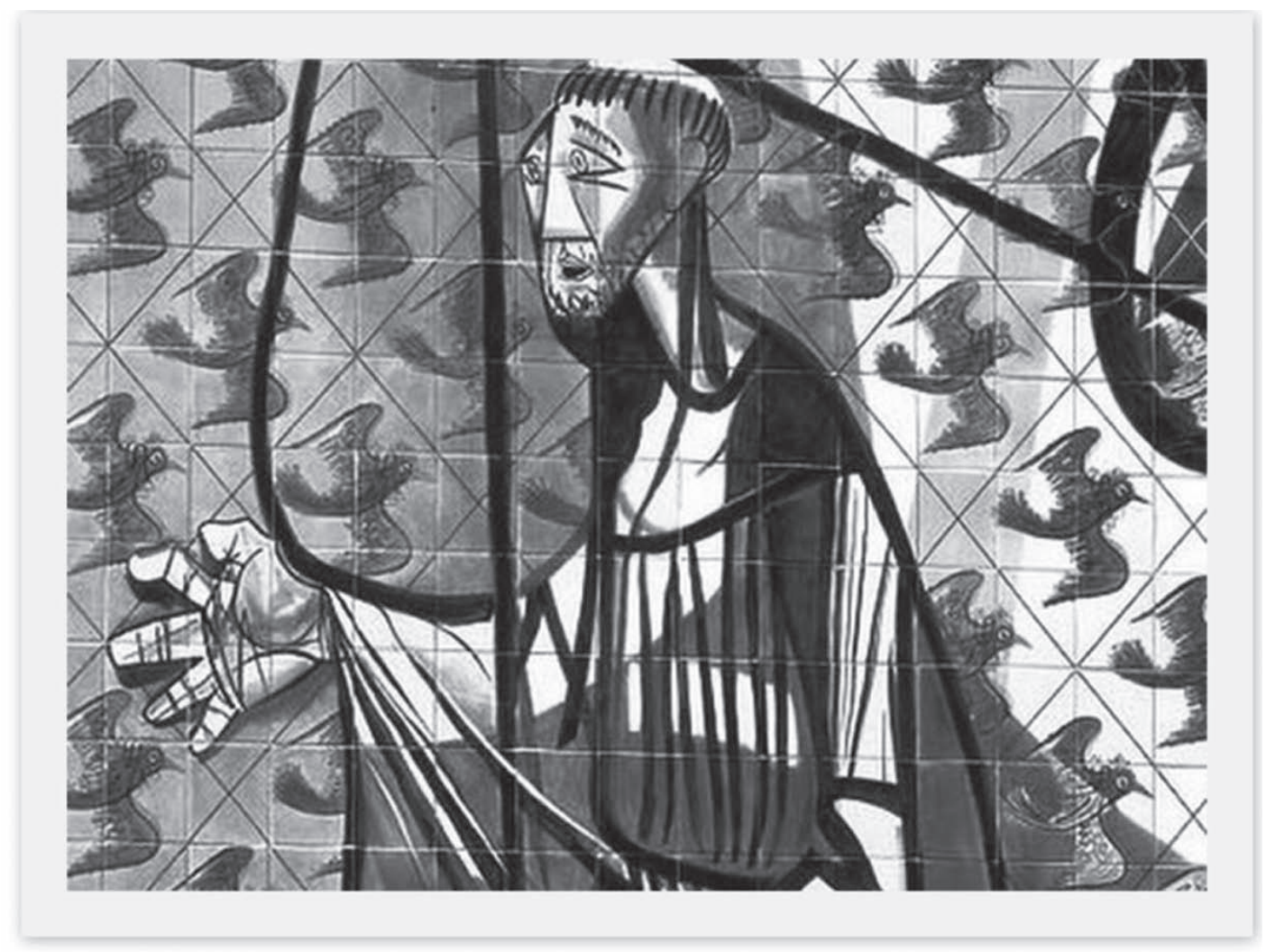

Imagem de São Francisco, por Candido Portinari.

não concordavam. Então, foi assim que muitos franciscanos foram perseguidos pelo poder porque importavam da França as ideias da democracia francesa.

Ele estava nesse contexto todo e, aqui no Rio de Janeiro, tinha a proximidade do poder central. Eles se reuniam aqui neste espaço. Eles trabalhavam também junto com a Maçonaria. Segundo me dizia um confrade amigo meu, que estudou fora, que tem uma formação acadêmica, a Maçonaria já existia antes de Cristo. Os illuminati já eram a semente da maçonaria, depois vieram os Templários, que construíam templos, depois maçons - o nome que pegou na França, que ficou. Então, os franciscanos e os adeptos da independência não tinham problemas em caminhar juntos, buscando o mesmo objetivo. Certamente existiam diferenças, pois logo em 1822 já se separaram. Conseguiram o objetivo, daí começam a prevalecer as diferenças.

Durante um conflito, ou você está de um lado ou de outro. Em uma fábrica, quando a situação é normal, tudo bem, trabalha-se, mas quando estoura uma greve, ou você está com o capital ou com o trabalho. Durante a Ditadura Militar, ou se estava com eles ou do outro lado. Como estávamos do outro lado, estávamos todos juntos. Nós e militantes do PCdoB caminhávamos juntos.

Lá na Brasilândia - onde eu morei - eu convivia muito com o pessoal do PCdoB: Raimundo Pereira, Irma Passoni, Benedito Cintra. O nosso coordenador latino-americano, Adolfo Pérez Esquivel, que dirigia uma entidade chamada "Serviço Paz e Justiça”, que atuava do México até a Patagônia, além de algumas células na Europa e simpatizantes nos Estados Unidos, sempre nos falava que em uma situação dessas, ou de lá ou de cá, temos que deixar claro de que lado estamos, e por isso vamos caminhar juntos com muitos grupos, com muitas ideologias, mas cada um com a sua identidade e nos respeitando, uma vez que o inimigo comum nos obriga a nos unir. 
Voltando ao Frei Francisco Sampaio, a maçonaria também estava do mesmo lado, certamente caminharam juntos, mas na hora que conseguiram o objetivo, começam a surgir as diferenças. Então ele tinha o apoio dos seus confrades. Uma congregação é na Igreja como uma tendência no partido. Existem os dominicanos, os franciscanos, os carmelitas, etc. Agora, o episcopado, a hierarquia, tenta não se identificar com nenhuma das tendências e tenta manter um espaço de acolher todo mundo, de congregação.

Embora eu tenha lido, não consegui entender qual era a relação dele com a hierarquia daquela época, mas certamente algum apoio ele deveria ter, porque senão eles o teriam enviado para outro lugar, não teria ficado aqui no Rio de Janeiro. Além de ajudar a elaborar o processo de independência, foi ele que escreveu o rascunho da carta que foi entregue a Dom Pedro I, solicitando que ele ficasse no Brasil e não voltasse a Portugal. Conseguiram nove mil assinaturas, que naquela época era muita coisa. E, daí, quando foram entregar a carta a Dom Pedro, ele disse aquela celebre frase: "se é para o bem de todos e a felicidade geral da nação diga ao povo que fico".

Depois ele rascunhou elementos da primeira Constituição, sendo que ele não era um republicano como a proposta da França, mas um parlamentarista monárquico. Neste momento ele já se separa de pessoas que caminharam junto com ele na independência, mas que tinham outra posição, cada um com sua identidade.

O fim de sua vida não teve coisas extraordinárias, ele se apagou normalmente, como qualquer ser humano. $\mathrm{Na}$ época dele, surgiram os estudos de Filosofia aqui no Convento. A intelectualidade estava muito ligada ao convento. Tinha o Frei Mariano Veloso, que foi um dos fundadores do Jardim Botânico, escreveu o livro Flora do Rio de Janeiro e foi um dos pioneiros da ecologia.

Naquela época, uma série de frades que contribuíam em diferentes campos, e o espaço de congregação deles, aqui no sul, era o Convento de Santo Antônio. Em 1747, morreu um frade chamado Fabiano de Cristo, que é até hoje muito reverenciado, os espíritas se apegam muito a ele. Fabiano não era padre e teve uma história muito parecida com a de Francisco de Assis. Era uma pessoa humilde, de Portugal, e que veio para cá, para o Eldorado da América, ficar rico no Brasil. E do Rio vai para Minas Gerais, ganha muito dinheiro com o ouro e fica riquíssimo. Vem morar em Paraty, e aí não sei o que aconteceu, mas ele mandou metade de sua riqueza para seus parentes em Portugal, distribuiu o restante por aqui, e veio ser enfermeiro e porteiro daqui do convento. Como porteiro atendia a todos e como enfermeiro ele tinha uma enfermaria. Aqueles escravos que velhos ou doentes estavam jogados nas ruas, Fabiano os trazia e cuidava deles aqui na enfermaria. Era uma figura que não teve este cunho político, mas certamente sua presença no meio desses outros contribuía.

Mais tarde frei Antônio de Sant'Ana Galvão também morou aqui. Depois, quando o Marquês de Pombal proibiu a entrada de novos candidatos para as ordens religiosas, houve um estrangulamento, principalmente dos jesuítas, mas também dos franciscanos. Ao final, os franciscanos de origem portuguesa praticamente faliram, ficou somente um frade aqui neste convento, frei João do Amor Divino Costa era o nome dele.

Depois, a pedido de Roma, vieram os alemães que estavam sofrendo a perseguição do Bismark na Alemanha. Chegaram no final do século XIX, e isso iniciou o processo de restauração dos franciscanos no Brasil inteiro, através dos alemães. Eles passaram a fazer um levantamento histórico deste convento e dos franciscanos, como este livro que tenho em mãos do frei Basílio Roewer, um alemão. Junto dele veio outro muito famoso, chamado Pedro Sinzig, que era músico, professor da Universidade, 
uma pessoa luminosa. Ele foi importante na música clássica, religiosa, não entrava na parte política, pois todos esses alemães vinham para um país estranho, fugidos de lá, sabendo que aqui tinha o mesmo clima, sendo que já não era mais a Igreja do padroado, já havia ocorrido a separação, então eles não podiam se envolver, por isso a presença política dos alemães era quase nula, mas a presença deles no campo da filosofia, dos estudos, da música foi muito forte.

Então entramos nesse emaranhado todo pela própria vida. Eu nunca tive interesse por estudos acadêmicos, não sei por que nunca gostei. Recebi uma proposta de me formar em jornalismo, em São Paulo, a Igreja financiaria, poderia estudar em Louvain na Bélgica. Outra proposta era para me formar em advocacia, mas eu era do estudo não acadêmico, nunca me adaptei à sistemática que a academia exige, prefiro, como mineiro, um aprofundamento mais matuto mesmo.

\section{C \& LC - Nesta resposta você destacou sua relação com Adolfo Pérez Esqui- vel. Explique como foi esta relação com ele, que recebeu o Nobel da Paz em 1980. Como foi este trabalho entre vocês?}

Eu trabalhava na Frente Nacional dos Trabalhadores, onde comecei em 1972. Em 1974, em Medellín, na Colômbia, foi organizada uma conferência por um casal, Hildegard Mayr e Jean Goss, ela austríaca e ele francês. O trabalho foi feito por esses dois europeus e um pastor norte-americano que morava no Uruguai. Eles estavam em um movimento chamado Movimento Internacional de Reconciliação, que acompanhava desde lá de fora a questão das ditaduras militares do Cone Sul. Eles começaram a marcar presença dentro da via da não violência e neste encontro, em 1974, tiraram uma coordenação latino-americana, na qual o Esquivel, que era um arquiteto e professor da Universidade de Buenos Aires, assim como artista e desenhista talentoso, foi indicado como um ponto de referência, não tinha nenhuma coordenação.

Em 1975, ele promoveu um $1^{\circ}$ Seminário de toda América Latina em Buenos Aires junto com a Amanda, sua esposa, e os três filhos, que eram crianças. Veio gente da França, da América toda. Eu fui porque a Frente Nacional do Trabalho, quando convidada, enviou em 1974 duas pessoas para o seminário em Medellín, a Carmem e o João Breno, presidente do sindicato do cimento, indústria dominada por aquele grupo J. J. Abdalla, do cimento Perus. Esse grupo já falava em firmeza permanente, em enfrentar o patrão com outra perspectiva. Mario Carvalho de Jesus dizia: “o Abdalla é patrão, é ladrão, é safado, mas é meu irmão e por isso, como tratar um irmão safado?” Essa já era a perspectiva da firmeza permanente.

Como duas pessoas já haviam participado da fundação inicial, nos convidaram novamente, e fomos três, os metalúrgicos Salvador Pires e Joaquim Rosinha, e eu, franciscano. Participamos deste encontro de uma semana em Buenos Aires e ali foi um passo de consolidação da organização a nível latino-americano.

Logo depois o Esquivel foi preso, permanecendo 18 meses na prisão. Foi colocado por três meses em uma solitária com um raio de luz em cima, com pouca claridade, tentaram levá-lo à loucura. Ele contou sobre as frases que estavam escritas nas paredes das prisões e tudo isso o marcou. Afirmou nunca se esquecer de uma frase que foi escrita com sangue, a dedo, que dizia: "Deus não mata”. Isso o marcou muito.

Ele se tornou uma referência da organização. Tínhamos em todos os países pelo menos um núcleo do que se chamava SERPAJ, Serviço, Paz e Justiça. Foi articulada uma coordenação executiva de vários movimentos. 
A tática das ditaduras era nos associar a grupos comunistas. Embora caminhássemos juntos, sem problemas, nossa identidade não era comunista, da União Soviética e de Cuba. Nossa postura era outra. Lembro-me que conheci o Genoíno [José Genoíno, deputado federal pelo PT] entre os que queriam a luta armada, e lembrei a ele do Daniel Ortega, da Nicarágua, que nos falou em São Paulo que não foi tão difícil vencer e se livrar da família Somoza, o problema era se livrar de Washington. Não há equilíbrio de forças. Perguntava se tinham uma bomba atômica para jogar neles, porque eles tinham várias para jogar em nós, e se precisassem eles jogariam. Por isso eu falei: põe a cabeça no lugar, você vai enfrentar um inimigo que é mil vezes mais poderoso que você, se a arma for a convencional. O Gandhi enfrentou o império inglês e, pelo menos naquele momento venceu com um apoio popular imenso e com uma arma própria dele que era o jejum e a oração, assim ele enfrentou o demônio do império inglês. Se você enfrentar o inimigo com as mesmas armas dele você perde, porque ele está treinado com suas próprias armas. Você tem que enfrentá-lo, mas com as suas próprias armas. Essa diferença de armamentos é muito importante.

E aí começou nosso movimento em várias partes da América Latina, e se seguiram as prisões e assassinatos na América Central, dois companheiros foram mortos. Em El Salvador, o Oscar Romero. Aqui no Brasil tínhamos o núcleo organizado, o SERPAJ, mas havia o SERPAJ estendido, contávamos com o Cardeal Arns, Dom Helder Câmara, Dom Pedro Casaldáliga, toda esta retaguarda.

Em São Paulo havia muita gente fugida da Argentina, saiam de lá e daqui seguiam para a Escandinávia, para a Suécia, para a França. Eles chegavam aqui, como as Mães da Praça de Maio, e procuravam o Cardeal Arns, que era a referência. Eu mesmo hospedei uma vez um casalzinho lá na favela. Estavam fugindo da morte. Ficavam aqui e buscávamos uma solução junto à ACNUR, que é aquele órgão da ONU.

Tinha uma jornalista que eu não me lembro do nome, que trabalhava na $\mathrm{BBC}$, $\mathrm{e}$ que possuía um canal para divulgar fora o que acontecia aqui. Eles isolavam a informação no Brasil, Uruguai, Argentina e Chile porque a imprensa toda estava nas mãos deles. Eu vi o nascimento da Globo, e o Roberto Marinho começou trabalhando a favor do império norte-americano e hoje os Marinho são a maior fortuna do Brasil. Quer dizer, deu dinheiro, né? Mas à custa de quantas vidas, de quanto sofrimento? Quando a gente conseguia vazar a notícia para fora do Brasil era perigoso para eles e entre os canais que tínhamos, um deles era o da BBC inglesa.

Sobre o Nobel, fui participando desse processo, ajudando, encaminhando, e em 1980, o mesmo grupo que criou o SERPAJ empreendeu uma luta danada, muitas articulações políticas, trabalhando o comitê que analisa os casos, as indicações, quem é quem. Então este grupo europeu, austríaco, criou esse movimento e o comitê analisou e outorgou ao Esquivel o Prêmio Nobel da Paz em 10 de dezembro de 1980. Mas o Adolfo deixou claro que quem estava recebendo o prêmio não era ele, mas sim todo o movimento e que ele não seria nada se não houvesse tudo isso, e assim fez questão que fosse junto dele dois representantes de cada país para receber este prêmio. Daqui do Brasil fomos eu e o João Breno, que estávamos desde o início do SERPAJ.

Lembro-me bem quando embarcamos, no dia 8 de dezembro, em um avião lá em Cumbica, São Paulo, com escala aqui no Rio. E quando pegamos o avião encontramos com a esposa do Adolfo que estava indo com o caçula para Oslo, onde seria entregue a premiação. Eu não falava nada em inglês, então foi muito bom encontrá-los porque quando nós chegamos a Copenhague, na Dinamarca, tínhamos que trocar de avião e 
não sabíamos como fazer. O filho dela, Leonardo, que sabia bem inglês, e já estava nos esperando no aeroporto, nos ajudou com os trâmites para irmos para Oslo. Quando saímos do Rio a temperatura estava $35^{\circ}$, viajamos a noite toda e meio-dia chegamos a Copenhague, com $-11^{\circ}$, mais tarde, em Oslo, $-25^{\circ}$, e naquela época eu usava uma barba e falei para o João Breno: estou me sentindo um Papai Noel aqui com esta neve.

Naquela época, o Prêmio Nobel da Paz era de 700 mil dólares, hoje está em torno de 1,2 milhão, que foi quanto deram para o Obama. Com esse dinheiro conseguimos financiar muito trabalho, só que não tínhamos condições de trazê-lo para a América. Uma companheira do SERPAJ, brasileira de família holandesa nos alertou: "não levem este dinheiro porque eles vão tomar de vocês". Então ela aplicou os recursos na Holanda e quando a gente precisava, mandava para cá.

Lá havia muitos latino-americanos, inclusive um paraguaio chamado Francisco cedeu o apartamento pequenino dele para nós ficarmos; o Adolfo ficou no hotel que estava reservado para ele. No dia 10 , dia da entrega do prêmio, haveria um jantar às 18 horas. O Adolfo falou que não estava sozinho, e era um jantar da equipe toda com o rei da Noruega. Acontecia também uma manifestação de rua a favor dos direitos humanos lá na Noruega, e Adolfo quis ir apoiá-la, já com o título de Nobel da Paz. Ele cometeu um pecado imperdoável na Europa, mas um Nobel da Paz se perdoa. Às 18 horas estávamos todos lá, com o rei e a corte toda, e o Adolfo atrasou 5 minutos e ficaram todos lá esperando, até o rei. No final do jantar, ele tinha que fazer o discurso de agradecimento. Falou de forma muito jeitosa, ao terminar o discurso ele guardou um pão no guardanapo e disse que estava levando para a América Latina como um sinal de que o povo da Noruega está disposto a repartir o pão deles com o povo da América Latina. Fez a crítica usando luvas de pelica. Depois, às 20 horas, ocorreu a cerimônia do Prêmio Nobel no Salão Nobre.

Lá o Prêmio Nobel é muito mais importante que aqui. A imprensa da Europa toda destaca, e o Nobel da Paz é mais importante que os outros prêmios Nobel. Ele fez um discurso de agradecimento e em seguida fomos rapidamente à Suécia, depois à Holanda, onde estava o pessoal do SERPAJ. Lá você tinha a noite e o dia boreal. Depois de uma semana dava um desespero porque não tinha sol, e eu não via a hora de voltar.

\section{C \& LC - E o trabalho do Grupo Tortura Nunca Mais, parecido com o do SERPAJ. Como você acompanhou o trabalho de Dom Paulo Evaristo Arns, de compilação das denúncias das torturas?}

Existem vários níveis de participação, sendo que uma coisa é estar no fogo da batalha e outra coisa é você colaborar guardando dados. A gente sabia que o Jaime Wright e o Cardeal Arns estavam coletando dados, cientificamente, e mandando para fora, mas eu não participei diretamente da confecção daquele livro, mas também atuávamos documentando. Este livro, "Brasil Nunca Mais”, no início não gostei do título, mas depois corrigiram para: "Brasil Tortura Nunca Mais". Porque deveria ser "Brasil Sempre", a não ser que eu volte à época de Pedro Álvares Cabral, com a Terra de Santa Cruz.

$\mathrm{E}$ a tortura continua sendo uma prática comum, não mudou nada. $\mathrm{O}$ poder continua usando a tortura como método de dominação, de extrair informação. Não mudou muito. Este trabalho eu achei muito bem feito, muito sério, não sei como eles conse- 


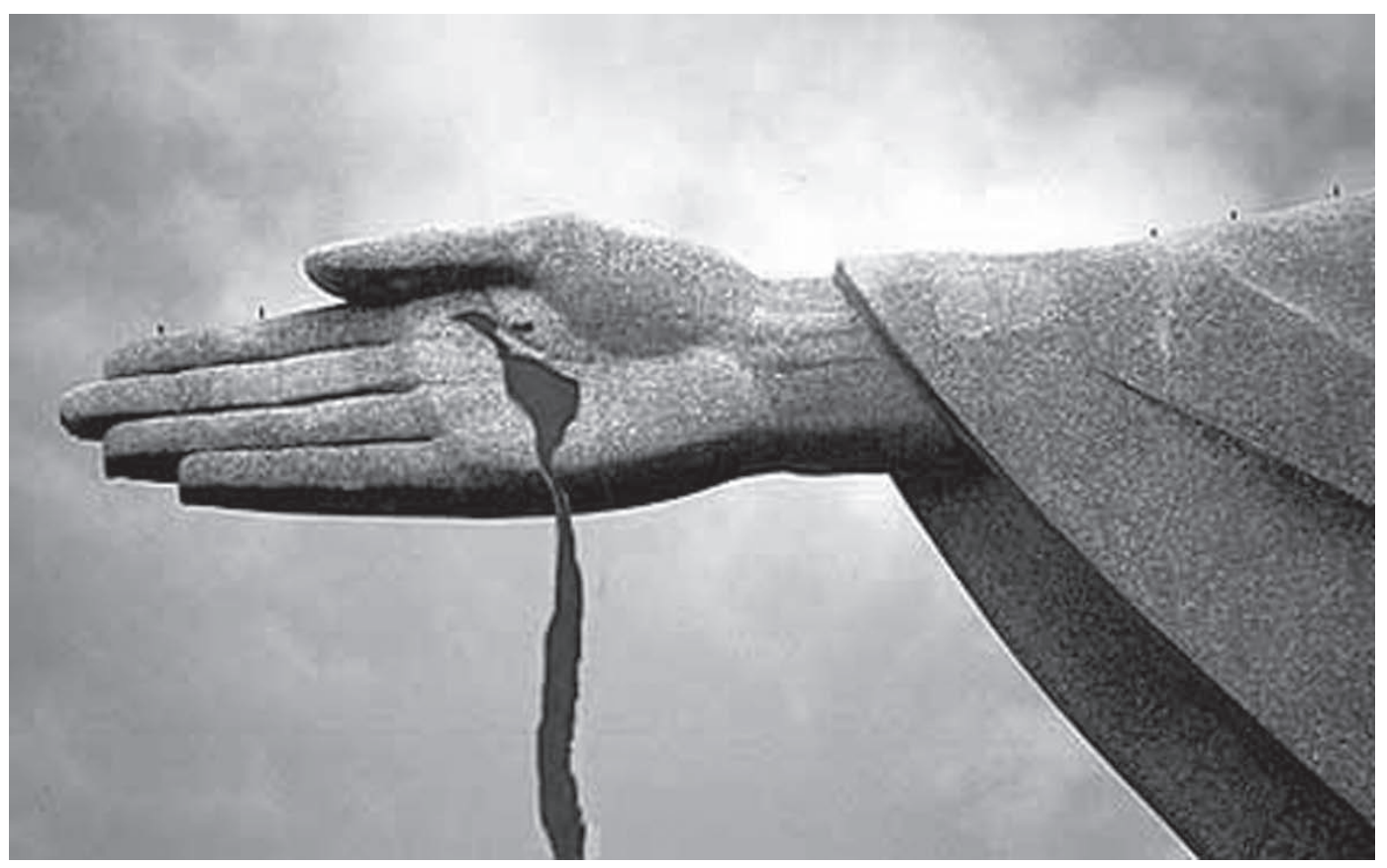

Montagem sobre detalhe da estátua de Jesus Cristo, Rio de Janeiro.

Fonte:http://matriz2006.blogs.sapo.pt/81 1493.html

guiram vazar tudo isso, porque era difícil. Nós mandávamos notícias, documentários, para o exterior sem que percebessem.

\section{C \& LC - Como foi essa articulação internacional para que essas denúncias pudessem sair do país?}

Uma das coisas que eu percebi no SERPAJ era a limitação que tem as ordens religiosas, que apesar de realizarem belíssimos trabalhos não conseguiam se articular. Tem a articulação da Igreja, mas a que não se envolve porque caso se envolvesse não teria retorno financeiro para manter as ordens. É um jogo difícil.

Eu percebi que esta articulação internacional é fundamental, como o exemplo da Joan Baez, que tinha o Centro de Não Violência de Santa Cruz, na Califórnia. Eles articularam um projeto de intercâmbio entre a luta da não violência da América Latina com os grupos de direitos humanos da América do Norte. Vinham para cá e a gente abria espaço para eles conhecerem, e também íamos para lá. Eu fui e fiquei seis meses em 1974. No primeiro mês para falar melhor a língua e me familiarizar, depois era pragmático, tinha que funcionar e produzir. Durante três ou quatro meses, com uma programação diferente. Tinha dias que eu encontrava com 10 grupos diferentes, para dialogar com eles sobre a situação daqui. Naquela época surgia muito a preocupação com a Nicarágua, com o problema dos Contras.

Eu aprendi muito, porque uma coisa é a imagem que o governo e o capitalismo dos EUA passam para todos nós, outra coisa é o povo norte-americano. Principalmente aqueles que têm compromisso com a justiça e os direitos humanos. Durante minha estadia lá, tive a oportunidade de conviver com este grupo. Não fiquei em hotel, estava sempre nas residências. Por exemplo, fiquei hospedado uma vez na casa de um general que perdeu todas as estrelas dele porque foi cassado do Exército por ter apoiado a Nicarágua. Por isso o chamavam de comunista e de antipatriota. Era um cara generoso, jogou sua patente fora e tomou uma posição política internacional 
correta. Então, esse apoio dos norte-americanos no caso dos Contras foi decisivo, assim como para nós este intercâmbio é fundamental, não dá para trabalhar sem isto.

C \& LC - O Papa Francisco teve uma participação importante como mediador na libertação dos Cinco Heróis Cubanos, assim como tem defendido o entendimento entre os povos, criticando a islamofobia, no caso das charges na França, e também se posicionando contra a guerra imperialista, quando os EUA ameaçaram invadir a Síria. Gostaríamos de perguntar como você vê a atuação do Papa Francisco depois de dois papados conservadores? Pode-se falar em uma volta da teologia da libertação?

O Adolfo Perez Esquivel divulgou uma nota sobre a semelhança entre o ataque contra a revista Charlie Hebdo e o 11 de Setembro. Neste caso, o papa se pronunciou, claro, não a favor do terrorismo, de se matar alguém, mas recordou também que não se pode insultar a religião do outro. Disse: "xinga minha mãe para você ver se não vai tomar um soco!" E um articulista da Folba de São Paulo, um tal de Reinaldo, disse que o Papa Francisco tinha que ficar calado. Ora, se ele diz lutar por liberdade de imprensa, mandar uma pessoa como o Papa Francisco, que não é qualquer papa, calar a boca é uma contradição enorme.

Sobre a teologia da libertação, embora eu acredite que a história não volte, creio que pode incorporar coisas novas ou do passado. Sobre o Vaticano II, por exemplo, tem gente falando que está na hora do Vaticano III, pois já mudou muito. Tenho minha visão de tudo isso, parto do princípio de que o processo histórico é dialético. Mas, nós podemos dizer as coisas com outros nomes. Em certo ambiente que não se pode falar em dialética, podemos falar em fermento e massa, isso é evangélico, mas estamos dizendo a mesma coisa. Cristo disse que o reino é como fermento na massa, ou seja, tese e antítese. Ou na filosofia oriental budista, o Yang e o Yin, tudo é o mesmo processo de desenvolvimento histórico.

Penso que durante a guerra fria também havia dois polos, dos quais veio uma síntese. Você tinha o polo do Capital e o polo do Trabalho. O primeiro representado por essas potências todas, mas capitaneado pelo que eu costumo chamar de império anglo-saxão sionista estadunidense. Quando eu estive lá percebi bem que são grupos afins. O anglo-saxão na América do Norte é uma coisa, é diferente de ser latino, como eu, brasileiro. $\mathrm{O}$ sionista é diferente de mim, ou de outro judeu que não é sionista. Não tem nada a ver com ser judeu, mas sionista. Quando falo estadunidense é porque os Estados Unidos tornaram a casa onde se reuniu tudo isso. Quando falo anglo-saxão, é pela presença alemã e saxônica, também. Eu estive em Las Vegas participando de uma manifestação antinuclear. Lá no campo de Nevada, um subterrâneo onde se realizavam explosões nucleares, que eram realizadas pela Inglaterra e pelos Estados Unidos. A independência dos EUA da Inglaterra não foi como a nossa, Brasil e Portugal, que foi para inglês ver, ou melhor, para os outros verem. Na Guerra das Malvinas, de que lado ficaram os Estados Unidos? Eles continuam ligados, não sei quem manda em quem.

Estados Unidos e União Soviética eram os dois polos daquela época. Eu nasci em 1940, considerando 1946, após a bomba de Hiroshima como o começo da guerra fria, e o seu final com a queda do muro, em 1989, neste período todo, a corda se esticava entre esses dois polos. É como um violão, se você não atarraxar a corda, ela fica bamba. Se você atarraxá-la na cavilha, afinar e tocar sai um som. Em cima de um som 
fundamental você afina todo o instrumento e sai música. Eu acho que no violão da história, o som fundamental partia desta corda esticada entre estes dois pontos. $\mathrm{Ou}$ você estava de um lado ou de outro. A teologia da libertação nasce deste clima, daí, por ela ser contra o capitalismo, nasce identificada com o outro lado, com o outro polo. Mas volto àquela história, você caminha junto, mas cada um tem sua identidade. Então, para mim pessoalmente, como vejo que foi para Leonardo Boff, Frei Betto, foi ótimo o contato com este polo do Trabalho. Ele me ajuda a fundamentar melhor toda uma visão evangélica, bíblica, religiosa, ao passo que naquele outro lado não há nada disso.

Vejo que hoje, com a queda do muro em 1989, a corda desatarraxou, as cavilhas bambearam. A corda está bamba, qualquer coisa que se toca, não sai música. Essa é a situação que estamos vivendo. Era bipolarizado, mas hoje está unipolar. Minha esperança é de que os BRICS ganhem força, consistência e ocorra uma nova polarização. Daí a corda vai esticar novamente. Começará a sair sons fundamentais nos quais virão movimentos religiosos, sociais. Enquanto não tiver esse som fundamental, a conjuntura continuará difícil. Eu tenho a esperança de que os BRICS mostrem um rumo, um norte diferente deste primeiro polo. 